\title{
Legal Origins, Religion and Health Outcomes: A Cross-Country Comparison of Organ Donation Laws
}

\author{
Guillem Riambau*1, Clin Lai², Boyu Lu Zhao², and Jean $\mathrm{Liu}^{2}$ \\ ${ }^{1}$ Universitat de Barcelona and Institutions and Political Economy Research Group \\ ${ }^{2}$ Department of Social Sciences, Yale-NUS College
}

November 23, 2020

\begin{abstract}
This paper investigates what drives countries to legislate presumed consent - making citizens organ donors by default unless they opt out - instead of explicit consent. Results reveal the following: First, civil law predicts presumed consent, which uncovers a mechanism by which an institution that long pre-dates transplantation medicine has an impact on current health outcomes. This is in line with previous research that has found that civil law regimes tend to be more comfortable with a centralized and activist government than common law ones. Second, Catholicism predicts presumed consent. This is consistent with previous research that shows Catholicism generally relies on more hierarchical structures and is less likely to encourage social responsibility among its members. Last, higher pro-social behavior decreases the likelihood of presumed consent. This could be explained by policy-makers trying not to discourage donations where pro-social behavior is high by making it look a requirement rather than an altruistic act. The implications of the findings are discussed, with a particular focus on policy-switches in organ donations.
\end{abstract}

Keywords: Organ donation laws, presumed consent, legal origins, religion, altruism, regulation. JEL: K32, I18, H8

\footnotetext{
${ }^{*}$ Contact info: griambau@gmail.com; Jean Liu (jeanliu@yale-nus.edu.sg); Clin Lai (clin.lai@u.yale-nus.edu.sg); Boyu Lu Zhao (lu.zhao.boyu@u.yale-nus.edu.sg). We would like to thank Julien Labonne and Risa Toha for useful insights. All errors are ours. Supplementary materials can be found at www.guillemriambau.com.

This work was supported by a grant awarded to Jean Liu from the National University of Singapore Humanities and Social Sciences research fund (grant number: HSS-1502-P02).
} 


\section{Introduction}

Across the World Health Organization member states, an estimated 126,670 organs were transplanted in 2015 (Global Observatory on Donation and Transplantation, 2015). This figure pales in comparison to the number of patients with end-stage organ failure: within the US alone, nearly 120,000 patients are on the transplantation waitlist, and an estimated 20 people die each day while waiting for a transplant (US Department of Health and Human Services, 2018). Despite progress in transplantation medicine, there remains a worldwide shortage of organs available.

In the face of a global shortage, countries vary widely in their rates of deceased organ donation (IRODAT, 2017). Cross-country analyses suggest that this may be influenced by the type of legislation implemented - whether a country presumes consent (such that residents are organ donors by default unless they 'opt out'), or requires explicit consent (where residents actively 'opt in' for organ donation) (Johnson and Goldstein, 2003; Abadie and Gay, 2006, Gimbel et al., 2003, Shepherd et al., 2014). Experimental research suggests that the default influences individual decision-makers by communicating a recommendation or by normalizing organ donation (Davidai et al., 2015, Mckenzie et al., 2006). Correspondingly, several countries have reported increases in the donor pool after presumed consent laws were passed (Shum and Chern, 2006, Rithalia et al., 2009).

While a causal link has not been established definitively, a systematic review of the literature concluded that "[i]n the four best quality between-country comparisons, presumed consent law or practice was associated with increased organ donation-increases of 25-30\%, 21-26\%, 2.7 more donors per million population, and 6.14 more donors per million population in the four studies" (Rithalia et al. 2009). Comparing similar countries that differ in their organ donation policies, Davidai et al. (2015) show that donation rates are six time greater in countries with presumed consent than in countries where donation requires explicit consent. Taken together, the extant literature suggests that the introduction of presumed consent would result in an increase of donation rates (Ugur, 2015, Li et al., 2013, Oz et al., 2003) and ultimately better health outcomes: "as impressive as 130,000 [annual] solid organ transplants worldwide may be, it is estimated that this number represents less than $10 \%$ of the global need" (WHO, 2020) 1

Although the potential implications of policy types are sizable, to the best of our knowledge, there has been no study that uses data from all continents to explore in a systematic manner what drives countries to choose presumed over explicit consent. This is what this paper does: by identifying mechanisms that have led countries to establish opt-out laws, this paper aims to inform future debates on the suitability of such laws in different contexts 2

\footnotetext{
${ }^{1}$ Other than presumed/explicit consent policies, there are other mechanisms that affect organ donation rates: among them, health system capacity is probably the most important. For instance, according to IRODaT, in countries like Spain, the USA, or Thailand, utilized deceased donors represent $100 \%$ of actual deceased donors. In other countries, however, this percentage may drop significantly. For instance, in Australia (93.3\%), Brazil (85.2\%), or Moldova (54.5\%), not all organs eventually reach a patient (see Watson and Dark 2012) for more details on technical advancements and challenges in transplantation). Other legal tools such as allocation priority to donors have been shown to also affect donation rates (Li et al. 2013 Zúñiga-Fajuri, 2010). See Bagheri (2005), Bendorf et al. (2013), or Callison and Levin (2016) for a discussion of other factors that explain different donation rates across countries.

${ }^{2}$ While (Shepherd et al. 2014), (Abadie and Gay, 2006) and (Healy 2005) suggest a few patterns, their studies do not aim to systematically uncover the determinants of presumed consent, and have significantly smaller sample sets for analysis (48, 22, and 17 countries, respectively) than ours (93 countries).
} 
Our data set includes all countries present in the International Registry on Organ Donation and Transplantation dataset (IRODaT - Gómez et al. (2014)). This leaves us with 93 countries from all five continents, which we categorize as explicit consent (if they require individuals to opt in as donors; $N=48$ ), presumed consent (if consent is assumed, unless indicated otherwise; $N=39$ ), and unclear/mixed policy (no legislation in this matter, no organs procurement from the deceased, no national organ networks, or unclear policy; $N=6$ ). We focus on those variables that the previous literature has considered to be relevant with regards to decisions about deceased organ donations (Abadie and Gay, 2006; Rithalia et al. 2009, Shepherd et al. 2014): religion and system of beliefs; public preferences for redistribution and for a public health system; economic and technological capacity to carry out transplants; legal traditions; and altruism. Hence, we collect data on economic development, social equality, health outcomes, state religiosity, religion preferences, legal system, urbanization, human development, political preferences, and altruism.

Results reveal a few key predictors. First, countries with civil law regimes are more likely to pass presumed consent laws. Second, compared to Protestant countries, Catholic countries are considerably more likely to hold presumed consent laws — we find no significant effects for other religious faiths. Third, most of our results suggest that countries with a larger religious population (including believers of any faith) do not have presumed consent policies. Fourth, presumed consent is less likely in countries with higher pro-social behavior. Taken together, these results suggest that the legislator is to some extent (but not fully) responsive to the preferences of the public $:^{3}$

\section{Data and empirical specification}

Countries are selected if they are in the International Registry on Organ Donation and Transplantation dataset (IRODAT - Gómez et al. (2014)). This leaves us with 93 countries, which we categorize as follows: explicit consent (countries that require individuals to opt in as donors; $N=48$ ), presumed consent (countries where consent is assumed, unless indicated otherwise; $N=39$ ), and unclear $/ \mathrm{mixed}$ policy (countries that do not have legislation in this matter, do not procure organs from the deceased, do not have national organ networks, or cannot be identified clearly as having either explicit or presumed consent; $N=6$ ). Table 1 and Table 2 in the supplementary materials provide the list of countries, their current legislation status and the sources used, whereas Figure 1 in the supplementary materials shows a world map with the main variables of interest: donation laws, legal origins, and religious faith.

For each country, we collect information on main religion, state religiosity and \% of religions population to capture the dominant credo and system of beliefs regarding the dead and their bodies — in particular, predominant religion of each country is determined as the largest religious community according to CIA (2018). Size of public sector, size of public health system and maximum tax rates are used to proxy political preferences, in particular preferences for redistribution and for a public health system.

\footnotetext{
${ }^{3}$ While much has been written on individual preferences for organ donations (see, for instance, Park et al. (2009), Wakefield et al. (2010), Salim et al. (2010), Bratton et al. (2011), or Miller et al. (2019), we are not aware of any study that looks at predictors of support specifically for organ donation laws. We encourage future research to shed light on this issue.
} 
GDP per capita, degree of urbanization, life expectancy, literacy rate, formal education levels, and OECD membership capture economic development and technological capacity. Mortality rate for ages 5-14 and physicians per thousand people capture health outcomes and capacity of the health system. Legal system captures the preferences and modus operandi of the legislator. Democracy index, Gini index and percentage of members of parliament who are women capture the level of equality and social development. Blood donations per capita and giving index score measure altruism. Lastly, religious and ethnic fragmentation proxy for social cohesion. Table 3 in the supplementary materials gives further details on the sources of all independent variables, whereas Table 4 provides the descriptive statistics and further details.

To find the key predictors of presumed consent, we adopt a machine learning based approach to sort through all the possible partial correlations between predictors and organ donation consent laws. We use the Lasso regression approach and an exhaustive search model (all details in sections 2.1 and 2.2 of the supplementary materials). Results are remarkably consistent across the different approaches we use: legal origins is the only variable that is always included. Main religion, and variables regarding health outcomes (children mortality rate), political preferences (public sector size) and political development (democracy index) are typically selected, too. When included, religious fractionalization and altruism tend to be a key predictor of organ donation laws as well — since data on ethnic fractionalization, religious fractionalization, and proxies for altruism exist only for a subset of countries, we do not include them in the main analysis.

In order to show the relative importance of each variable, and the direction of the correlation, we run the following linear model using the variables most frequently selected by the machine learning algorithms:

$$
\text { Policy }_{i}=\alpha+X_{i}^{\prime} \beta+\varepsilon_{i}
$$

Policy $_{i}$ is a dummy that captures presumed consent ( $1=$ presumed consent; $0=$ explicit consent), $i$ denotes country, and $X$ denotes the vector of independent variables. The variables included in $X$ are legal origins, mortality rate (ages 5-14), dominant religion 4 state religiosity, \% who are religious, log of GDP per capita, size of the public sector, democracy index, degree of urbanization, and OECD membership. The supplementary materials show that results hold when we include all remaining ones in a series of robustness checks.

\section{Results}

Table 1 confirms that the strongest predictors of presumed consent are legal origins and religion. Civil law countries are more likely than common law countries to have an opt-out system. The magnitude of the observed effect is large: caeteris paribus, civil law countries are five times more likely to pass presumed

\footnotetext{
${ }^{4}$ We classify them into 'Catholic', 'Christian Orthodox', 'Protestant', 'Islam', and 'Other'. We acknowledge that classifying religious affiliation into five categories inevitably simplifies the analysis. Our categories follow the convention of similar cross-country studies in epidemiology (e.g. WHO (2006)) and economics (e.g. the seminal work on religion and attitudes by (Guiso et al. 2003).
} 
consent laws than common law countries 5

Table 1: Drivers of presumed consent legislation

\begin{tabular}{|c|c|c|c|c|}
\hline \multicolumn{5}{|c|}{ Dependent Variable: Presumed consent (opt-out) } \\
\hline & (1) & $(2)$ & $(3)$ & $(4)$ \\
\hline Civil Law & $\begin{array}{l}0.269^{*} \\
(0.146)\end{array}$ & $\begin{array}{l}0.278^{*} \\
(0.155)\end{array}$ & $\begin{array}{l}0.319 * * \\
(0.155)\end{array}$ & $\begin{array}{l}0.330^{* *} \\
(0.156)\end{array}$ \\
\hline Mortality (5-14 year old) & $\begin{array}{l}-0.074^{* *} \\
(0.033)\end{array}$ & $\begin{array}{l}-0.078 \\
(0.057)\end{array}$ & $\begin{array}{l}-0.068 \\
(0.057)\end{array}$ & $\begin{array}{l}-0.064 \\
(0.056)\end{array}$ \\
\hline \multicolumn{5}{|l|}{ Main religion: } \\
\hline Catholic & $\begin{array}{l}0.224 \\
(0.160)\end{array}$ & $\begin{array}{l}0.318^{*} \\
(0.167)\end{array}$ & $\begin{array}{l}0.399 * * \\
(0.171)\end{array}$ & $\begin{array}{l}0.446^{* *} \\
(0.173)\end{array}$ \\
\hline Orthodox & $\begin{array}{l}0.151 \\
(0.199)\end{array}$ & $\begin{array}{l}0.267 \\
(0.248)\end{array}$ & $\begin{array}{l}0.311 \\
(0.246)\end{array}$ & $\begin{array}{l}0.359 \\
(0.244)\end{array}$ \\
\hline Islam & $\begin{array}{l}0.095 \\
(0.183)\end{array}$ & $\begin{array}{l}0.267 \\
(0.252)\end{array}$ & $\begin{array}{l}0.382 \\
(0.256)\end{array}$ & $\begin{array}{l}0.462^{*} \\
(0.256)\end{array}$ \\
\hline State religion & & $\begin{array}{l}0.168 \\
(0.148)\end{array}$ & $\begin{array}{l}0.268^{*} \\
(0.156)\end{array}$ & $\begin{array}{l}0.270^{*} \\
(0.155)\end{array}$ \\
\hline$\%$ religious & & & $\begin{array}{l}-0.007^{*} \\
(0.004)\end{array}$ & $\begin{array}{l}-0.008^{* *} \\
(0.004)\end{array}$ \\
\hline Public sector size & & $\begin{array}{l}0.006 \\
(0.005)\end{array}$ & $\begin{array}{l}0.006 \\
(0.005)\end{array}$ & $\begin{array}{l}0.006 \\
(0.005)\end{array}$ \\
\hline $\log ($ GDP) p.c. & & $\begin{array}{l}-0.088 \\
(0.096)\end{array}$ & $\begin{array}{l}-0.072 \\
(0.095)\end{array}$ & $\begin{array}{l}-0.059 \\
(0.093)\end{array}$ \\
\hline Democracy index & & $\begin{array}{l}0.115 \\
(0.085)\end{array}$ & $\begin{array}{l}0.128 \\
(0.084)\end{array}$ & $\begin{array}{l}0.151^{*} \\
(0.083)\end{array}$ \\
\hline Urbanization & & $\begin{array}{l}-0.002 \\
(0.004)\end{array}$ & $\begin{array}{l}-0.003 \\
(0.004)\end{array}$ & $\begin{array}{l}-0.004 \\
(0.004)\end{array}$ \\
\hline Observations & 87 & 87 & 87 & 85 \\
\hline $\mathrm{R}^{2}$ & 0.225 & 0.290 & 0.319 & 0.350 \\
\hline
\end{tabular}

Dependent Variable: 1=Presumed consent ("opt-out"); $0=$ Explicit consent ("opt-in"). Civil Law: legal system based on civil law only (base category: common law or neither. Unreported category: both civil law and common law). State religion: dummy variable for holding an official, government-endorsed religion. Main religion: base category='Other Christian'; unreported category='Other'. Not shown: OECD membership (dummy). See Table 3 and Table 4 in the supplementary materials for more details on the variables.

The influence of a country's predominant religion does not pale in comparison. Namely, countries where Catholicism dominates are around four times more likely to enact presumed consent than countries where Protestantism dominates. We find no significant results for other religions when we compare them to Catholicism. Column (4) excludes Australia and Germany, since both countries have virtually the same number of Protestants and Catholics according to official statistics ${ }^{6}$ Excluding both does not alter our results: When we include them, the resulting p-values for Catholicism are 0.043, 0.024, 0.020, and 0.039 (for all four possible combinations). The impact of health outcomes (proxied by child mortality) is on the other hand, less clear. Whereas results suggest that countries with lower child mortality rates are more likely to have presumed consent, this effect vanishes once we control for political and social

\footnotetext{
${ }^{5}$ In fact, out of the 25 countries with common law in our dataset, only four have implemented presumed consent. Out of this four, two have a "pure" common law system (Singapore and Bahrain), whereas the other two have a mixed common law/civil law system (Malta and Norway).

${ }^{6}$ Whereas the CIA World Factbook specifies that there are $0.7 \%$ more Protestants than Catholics in Australia, the Australian Bureau of Statistics recently stated that "Catholicism is the largest Christian grouping in Australia" albeit by a small margin (Australian Bureau of Statistics, 2017), and the US Freedom Report on Australia does not provide a clear answer on the largest denomination in the country (US Department of State, 2016)).
} 
development outcomes.

Apart from legal origins and religious faith, we find that countries with a larger proportion of religious population - regardless of faith - tend to prefer explicit consent systems. Everything else held constant, a country where half its residents hold any religious faith will implement presumed consent with a probability close to $80 \%$, whereas that probability drops to around one third for a country where everyone is religious. However, as discussed below, this result is not robust to all specifications. Table 9 in the supplementary materials replicates Table 1 with the inclusion of countries where the policy is not clear (i.e., where the dependent variable is 1 for presumed consent and 0 for explicit consent/no policy/unclear/mixed). All results hold.

\subsection{Robustness checks and alternative explanatory variables}

Figure 3 in the supplementary materials shows that results for civil law, Catholicism, and altruism are robust to the inclusion of all remaining controls described above. However, results regarding proportion of religious population reveal that, whereas clearly suggestive, we cannot make statements as conclusive as with the case of the other three explanatory variables.

Using data from Montalvo and Reynal-Querol (2005) and Dražanová (2019), we also assess whether ethnic and religious fragmentation can predict presumed consent (as mentioned above, since data on these dimensions exists only for a subset of countries, we do not include them in the main analysis). Results are unambiguous: countries with higher religious fragmentation are less likely to have presumed consent. This suggests that policy-makers might be more reluctant to impose organ donations where societies are less homogeneous. All details can be found in sections 2.1 and 2.2 of the supplementary materials.

Finally, Figure 4 in the supplementary materials shows that — with only the exception of altruism - no other variables have explanatory power at conventional statistical levels: when we include measures that capture pro-social behavior, we find that lower levels of altruistic behavior are associated with opt-out consent systems - see Figure 1) below (as with religious fractionalization, we test altruism separately because of data constraints). We proxy altruism with 'giving index', a measure constructed by the Charities Aid Foundation by means of a worldwide survey (Charities Aid Foundation, 2017). Specifically, it is computed based on the proportion of people who report one or more of the following non-health related altruistic behavior in the month prior to being interviewed: helping a stranger, donating money, and volunteering. We find that countries in which residents report higher levels of giving are more likely to enact explicit consent. To be precise, the predicted probability of having opt-out for a country with a giving score of $25 \%$ is around three times larger than for a country with a score of $50 \%$.

\section{Discussion and remarks}

We find that the historical origin of a country's laws is the strongest predictor of organ transplant policies: countries with civil law regimes are more likely to enact presumed consent policies, whereas common law countries are more likely to prefer explicit consent rules. 


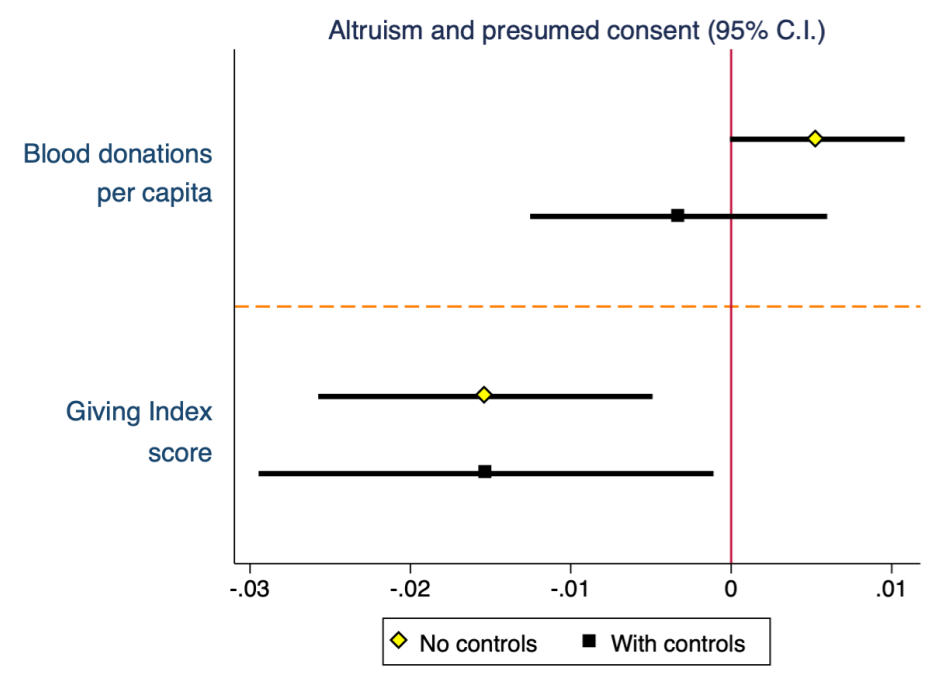

Figure 1: $95 \%$ confidence intervals. Bars with an empty diamond: no controls added. Bars with a solid square: full set of controls. Model: Policy $y_{i}=\alpha+X_{i}^{\prime} \beta+\gamma z_{i}+\varepsilon_{i}$, where $z$ is the relevant variable, Policy $_{i}$ is a dummy for presumed consent, $X_{i}$ is a vector of country specific controls: mortality rate among those aged 5-14 year old, state religion, main religion, percent who are religious, legal origins, GDP per capita, democracy index, and OECD membership. $N=79$.

Historically, the common law tradition originates from the laws of England, whereas the civil law tradition has its roots in the Roman law, and was adopted and exported by France. These two legal systems operate in very different ways: civil law relies on professional judges, legal codes, and written records; whereas common law focuses on lay judges, broader legal principles, and oral arguments (Glaeser and Shleifer, 2002). Furthermore, common law follows the legal principle of stare decisis, - i.e., precedent is binding - while this is not necessarily the case for civil law (Dainow, 1996). Since legal traditions were typically introduced into colonized countries through conquest, persisted after independence, and varied between common and civil law colonizers, they provide a natural experiment for researchers to trace the effects of legal system variation on various outcomes (Anderson, 2018).

Among other findings, civil law regimes are more likely to impose military conscription Mulligan and Shleifer, 2005), to have government ownership of media (Djankov et al., 2003) and banks La Porta et al. (2002), to strictly regulate labor markets (Botero et al., 2004), to favor a heavier hand of government ownership and more hierarchical regulation (La Porta et al., 2008, D'Amico and Williamson, 2015), and to be more comfortable with a centralized and activist government than common law regimes (Mahoney, 2001). Adding to this literature, our findings suggest that donation laws also tend to reflect the polity's default position on broader conceptions of the relationship between the individual and the state (Healy, 2005). Notably, by highlighting how the more interventionist approach of civil law countries extends to the area of organ donation laws, our results underscore how legal origins have consequences that extend into the sphere of health: previous research has suggested that better health outcomes in countries with civil law legal origin seem to result from greater decentralization of government funds, higher rates of urbanization, and less ethnic fractionalization (Scanlon, 2016). Results in this paper add a fourth mechanism: presumed consent. While it has been claimed that 'default saves lives' in organ donation 
(Johnson and Goldstein 2003), the evidence suggests that a country's legal origins is what dictates its default in the first place. This complements recent work highlighting the impact of legal origins on the HIV rates of females in Sub-Saharan Africa (Anderson, 2018).

Our finding has also relevant implications for Legal Origins Theory: critics have argued that legal origins are "merely a proxy" for political, historical or social developments that occurred as the legislation was being developed (La Porta et al. 2008, Spamann, 2015). In clear contrast to this, organ donation laws did not appear until well into the second half of the 20th century - organ transplants were not feasible in a safe and systematic way until the 1970s:7 That is, many decades after the establishment of the legal system. While it is plausible that a lurking unobserved confounder explains both legal origins and contemporary policies, it is likely that the major channel by which legal origins may have affected organ donation laws is via the modus operandi inherent to each type of legal system — i.e., a preference for "private market allocations vs. a preference for state-based allocations" (La Porta et al. 2008). In this sense, organ donation laws are a perfect case in point to illustrate that countries design laws consistently with their legal traditions, which is in essence the core of Legal Origins Theory.

In this respect, future research should shed light on whether legal origins have a similar predictive power on other contemporary policies. For instance, with regards to the current Covid-19 pandemic, results in this paper and the previous literature suggest that civil law and common law countries would respond in a different fashion. Whereas civil law countries could be expected to implement centralised policies with very specific regulations on what citizens may or may not do, common law countries would, in principle, be expected to respond in a more de-centralized, less regulatory-driven fashion.

The second key predictor of donor legislation is religion. Catholic countries are nearly 30 percentage points more likely to legislate presumed consent than Protestant-dominant countries. Notably, this is not driven by religious credo, since formally all religions endorse deceased organ donation (Bruzzone, 2008). In particular, Protestant and Catholic leaders express equal levels of support to deceased donations Oliver et al. 2010). We thus contend that our observed findings reflect the institutional and social dynamics induced by these two different religious affiliations.

In previous research, Protestantism has been associated with higher levels of altruism Mocan and Tekin, 2007; Bekkers and Schuyt, 2008). It has been shown to encourage lay members to engage in voluntary activities both inside and outside the church (Lam, 2006, Arruñada, 2010), to encourage the pursuit of social responsibility among its members (relative to other religions) (Lam, 2002), and to rely on more horizontal structures than Catholicism (Rose, 1954; Lipset, 1990) 8 On the other hand, Catholicism has been characterised by more hierarchical structures and a greater reliance on the government to take responsibility, favoring the provision of social services within its own hierarchy and limiting lay involvement. In particular, lower levels of volunteering have been found among Catholics as compared to Protestants (Lam, 2002). Although religious leaders in Catholic and Protestant countries have no direct say on legislation, historically dominant religions are likely to leave a long-lasting imprint on cultures

\footnotetext{
7 "There was simply no need for such laws." (Howard et al. (2012), p. 9). See (https://www.organdonor.gov/about/ facts-terms/history.html) for details.

${ }^{\circ}$ See $($ Kahl 2005 ) for a discussion on religious roots of altruistic attitudes
} 
and may shape people's attitudes - even if they are not religious themselves (Halman and Luijkx, 2006 . Kaasa, 2013). That is to say, religions may have affected the legislator's policy choices through the political culture they contribute to shape. In this light, the state having limited say regarding organs from the deceased seems to fit within the general lack of hierarchization intrinsic to Protestantism, leaving more room for individual altruism to dictate organ donation decisions.

Beyond the Protestant-Catholic distinction, countries with a larger religious population (including believers of any faith) are less likely to hold opt-out policies. Although formally no major religion opposes donations (Bruzzone, 2008), research has shown that religiosity is negatively associated with willingness to donate organs (Ugur, 2015, Wakefield et al., 2010, Rumsey et al., 2003, Wong, 2010, van Dalen and Henkens, 2014). These two results suggest policy-makers are responsive to citizens' demands to some extent. If religious individuals have a stronger hesitation to donate and this translates into lobbying against presumed consent, such political pressure is more likely to be successful in countries where the presence of religious groups (of any kind) is more widespread. Nonetheless, we caution that - unlike dominant religion - the proportion of religious adherents is not robust across all model specifications. Further, the measure of religiosity that we use (from the CIA World Factbook) is not as precisely estimated as other variables in our data set (details in the supplementary materials). Thus, we are circumspect regarding the association between the proportion of a religious population and organ donation laws.

Finally, our results suggest that presumed consent systems are associated with lower levels of nonhealth related philanthropy and lower levels of pro-social behaviour. This confirms the findings in Shepherd et al. (2014). Although this result may seem surprising, experimental research suggests that opt-in policies portray donation as an active, altruistic act (Davidai et al. 2015; Miller et al. 2019). This portrayal aligns with the norm of giving as an active process that exists in countries where philanthropy is high (Shepherd et al. 2014). Conversely, opt-out policies depict donation as a mundane form of community service, akin to paying one's tax (Davidai et al., 2015, Miller et al., 2019). In turn, this representation may encourage donation in countries where altruism is lower. In other words, if policy-makers rationally respond to citizens' preferences and social norms, they should enact presumed consent where altruism is lower, and require explicit consent where pro-social behavior is higher. Our data is consistent with this hypothesis.

In a period when many countries are re-visiting their organ donation laws (only in 2018, Argentina, the Netherlands and Ukraine have updated them), our findings have relevant policy implications. However central the role of legal origins may be, the salience of the religious and social values dimensions highlight the importance of recognizing that adoption of presumed consent does not occur in a vacuum. In many recent commentaries, leading policy makers and researchers have been advocating for a presumed consent policy in a blanket manner - as if it were the panacea for the worldwide organ shortage. However, findings in this paper and previous research emphasize the need for parallel measures in order to guarantee the success of opt-out systems (Bilgel, 2012, Domínguez and Rojas, 2013, Li et al., 2013; Shepherd et al. 2014 Zúñiga-Fajuri 2010). Similarly, several countries have debated this possibility in the public space, but concluded that cultural factors rendered an opt-out policy impractical (Etheredge et al., 2018). This 
highlights that governments would do wisely to anticipate more resistance in contexts that may not be as friendly.

As La Porta et al. (2008) note, states may apply the tools characteristic of their legal style to areas of regulation where they are inappropriate. Presumed consent laws are likely to be a good example if the legislator fails to register public preferences that are opposed to such procedures. For instance, if the legislator in a common law country aims to implement presumed consent, it is likely to face resistance from different actors (e.g., civil society or the bureaucracy). In that case, it would be wise to learn from Norway or Malta, countries that have a mixed common law/civil law system and have successfully implemented presumed consent 9 More generally, by highlighting the characteristics most frequently associated to organ donation laws, this paper provides a checklist of possible resistance factors for policymakers who may try to implement presumed consent. Overall, the implication is clear: when calls are made for governments to switch to presumed consent, discussions should move beyond behavioral science research to consider the broader socio-cultural context.

\section{References}

Abadie, Alberto, and Sebastien Gay. "The impact of presumed consent legislation on cadaveric organ donation: a cross-country study." Journal of health economics 25, no. 4 (2006): 599-620.

Anderson, Siwan. "Legal Origins and Female HIV." American Economic Review 108, 6 (2018): 1407-39.

Arruñada, Benito. "Protestants and Catholics: Similar work ethic, different social ethic." The Economic Journal 120, no. 547 (2010): 890-918.

Australian Bureau of Statistics. 2016 Census data reveals "no religion" is rising fast, 27 June 2017. Available at http://www.abs.gov.au

Bagheri, Alireza. "Organ transplantation laws in Asian countries: a comparative study." Transplantation Proceedings vol. 37, no. 10, (2005) pp. 4159-4162.

Bendorf, Aric, Bruce A. Pussell, Patrick J. Kelly, and Ian H. Kerridge. "Socioeconomic, demographic and policy comparisons of living and deceased kidney transplantation rates across 53 countries." Nephrology 18, no. 9 (2013): 633-640.

Bilgel, Firat. "The impact of presumed consent laws and institutions on deceased organ donation." The European Journal of Health Economics 13, no. 1 (2012): 29-38.

Bekkers, Ren, and Theo Schuyt. "And who is your neighbor? Explaining denominational differences in charitable giving and volunteering in the Netherlands." Review of Religious Research (2008): 74-96.

Botero, Juan C., Simeon Djankov, Rafael La Porta, Florencio Lopez-de-Silanes, and Andrei Shleifer. "The regulation of labor." The Quarterly Journal of Economics 119, no. 4 (2004): 1339-1382.

Bratton, Charles, Kenneth Chavin, and Prabhakar Baliga. "Racial disparities in organ donation and why." Current opinion in organ transplantation 16, no. 2 (2011): 243-249.

Bruzzone, Patricio. "Religious aspects of organ transplantation." In Transplantation proceedings, vol. 40, no. 4, pp. 1064-1067. Elsevier, 2008.

Callison, Kevin, and Adelin Levin. "Donor registries, first-person consent legislation, and the supply of deceased organ donors." In Journal of health economics, 49 (2016): 70-75.

Charities Aid Foundation. "CAF World Giving Index 2017", https://www.cafonline.org/about-us/ publications/2017-publications/caf-world-giving-index-2017 [Accessed May 9, 2018].

\footnotetext{
${ }^{9}$ Malta ranks 10, and Norway ranks 16 in donations per million people $\sqrt{\text { IRODAT }}(2020)$ ).
} 
Central Intelligence Agency (USA), The world factbook. Available at https://www.cia.gov/library/ publications/the-world-factbook/ [Accessed May 9, 2018].

D'Amico, Daniel J., and Claudia Williamson. "Do legal origins affect cross-country incarceration rates?." Journal of comparative economics 43, no. 3 (2015): 595-612.

Dainow, Joseph. "The civil law and the common law: Some points of comparison." Am. J. Comp. L. 15 (1966): 419.

Davidai, Shai, Thomas Gilovich, and Lee D. Ross. "The meaning of default options for potential organ donors." Proceedings of the National Academy of Sciences 109, no. 38 (2012): 15201-15205.

Djankov, Simeon, Edward Glaeser, Rafael La Porta, Florencio Lopez-de-Silanes, and Andrei Shleifer. "The new comparative economics." Journal of comparative economics 31, no. 4 (2003): 595-619.

Domínguez, J., and J. L. Rojas. "Presumed consent legislation failed to improve organ donation in Chile." Transplantation proceedings 45, no. 4 (2013): 1316-1317.

Dražanová. Historical Index of Ethnic Fractionalization Dataset (HIEF), Harvard Dataverse, V1.0 https : //doi.org/10.7910/DVN/4JQRCL [Accessed January 20, 2020].

Etheredge, Harriet, Claire Penn, and Jennifer Watermeyer. "Optin or optout to increase organ donation in South Africa? Appraising proposed strategies using an empirical ethics analysis." Developing world bioethics 18, no. 2 (2018): 119-125.

Gimbel, Ronald W., Martin A. Strosberg, Susan E. Lehrman, Eugenijus Gefenas, and Frank Taft. "Presumed consent and other predictors of cadaveric organ donation in Europe." Progress in Transplantation 13, no. 1 (2003): 17-23.

Glaeser, Edward L., and Andrei Shleifer. "Legal origins." The Quarterly Journal of Economics 117, no. 4 (2002): 1193-1229.

Global Observatory on Donation and Transplantation. "Organ Donation and Transplantation Activities, 2015 Report." http://www.transplant-observatory.org [Accessed May 9, 2018].

Gómez, M. P., Blanca Pérez, and M. Manyalich. "International registry in organ donation and transplantation - 2013." In Transplantation proceedings, vol. 46, no. 4, pp. 1044-1048. Elsevier, 2014.

Guiso, Luigi, Paola Sapienza, and Luigi Zingales. "People's opium? Religion and economic attitudes." Journal of monetary economics 50, 1 (2003): 225-282.

Halman, Loek, and Ruud Luijkx. "Social capital in contemporary Europe: evidence from the European Social Survey." Portuguese journal of social science 5, no. 1 (2006): 65-90.

Healy, Kieran. The political economy of presumed consent. (2005). Available at https://escholarship. org/uc/item/33x4463s [Accessed May 9, 2018].

Howard, Richard J., Danielle L. Cornell, and Larry Cochran. "History of deceased organ donation, transplantation, and organ procurement organizations." Progress in transplantation 22, 1 (2012): 6-17.

International Registry in Organ Donation and Transplantation. "Final Numbers 2016." Available at http://www.irodat.org/img/database/pdf/IRODaT [Accessed May 9, 2018].

International Registry in Organ Donation and Transplantation. "Preliminary Numbers 2019." Available at http://www.irodat.org/img/database/pdf/IRODaT [Accessed April 1, 2020].

Johnson, Eric J., and Daniel Goldstein. "Do defaults save lives?" Science (2003): 1338-1339.

Kaasa, Anneli. "Religion and social capital: Evidence from European countries." International Review of Sociology 23, no. 3 (2013): 578-596.

Kahl, Sigrun. "The religious roots of modern poverty policy: Catholic, Lutheran, and Reformed Protestant traditions compared." European Journal of Sociology (2005): 91-126..

La Porta, Rafael, Florencio Lopez-de-Silanes, and Andrei Shleifer. "Government ownership of banks." The Journal of Finance 57, no. 1 (2002): 265-301. 
La Porta, Rafael, Florencio Lopez-de-Silanes, and Andrei Shleifer. "The economic consequences of legal origins." Journal of economic literature 46, no. 2 (2008): 285-332.

Lam, Pui-Yan. "As the flocks gather: How religion affects voluntary association participation." Journal for the scientific study of religion 41, no. 3 (2002): 405-422.

Lam, Pui-Yan. "Religion and civic culture: A crossnational study of voluntary association membership." Journal for the scientific study of religion 45, no. 2 (2006): 177-193.

Li, Danyang, Zackary Hawley, and Kurt Schnier. "Increasing organ donation via changes in the default choice or allocation rule." Journal of health economics 32, no. 6 (2013): 1117-1129.

Lipset, Seymour Martin. Continental divide: The values and institutions of the United States and Canada. Routledge, 2013.

Mahoney, Paul G. "The common law and economic growth: Hayek might be right." The Journal of Legal Studies 30, no. 2 (2001): 503-525.

McKenzie, Craig RM, Michael J. Liersch, and Stacey R. Finkelstein. "Recommendations implicit in policy defaults." Psychological Science 17, no. 5 (2006): 414-420.

Miller, Jordan, Sinéad Currie, and Ronan E. OCarroll. "If I donate my organs it's a gift, if you take them it's theft: a qualitative study of planned donor decisions under opt-out legislation." BMC public health 19, no. 1 (2019): 1463.

Mocan, Naci, and Erdal Tekin. "The determinants of the willingness to donate an organ among young adults: evidence from the United States and the European Union." Social Science $E^{8}$ Medicine 65, no. 12 (2007): 2527-2538.

Montalvo, José G., and Marta Reynal-Querol. "Ethnic polarization, potential conflict, and civil wars". American Economic Review 95, no. 3 (2005): 796-816.

Mulligan, Casey B., and Andrei Shleifer. "Conscription as regulation." American Law and Economics Review 7, no. 1 (2005): 85-111.

Oliver, Michael, Alexander Woywodt, Aimun Ahmed, and Imran Saif. "Organ donation, transplantation and religion." (2010): 437-444.

Oz, Mehmet C., Aftab R. Kherani, Amanda Rowe, Leo Roels, Chauncey Crandall, Luis Tomatis, and James B. Young. "How to improve organ donation: results of the ISHLT/FACT poll." The Journal of Heart and Lung Transplantation 22, no. 4 (2003): 389-410.

Park, Hee Sun, Sandi W. Smith, and Doshik Yun. "Ethnic differences in intention to enroll in a state organ donor registry and intention to talk with family about organ donation." Health Communication 24 , no. 7 (2009): 647-659.

Rithalia, Amber, Catriona McDaid, Sara Suekarran, Lindsey Myers, and Amanda Sowden. "Impact of presumed consent for organ donation on donation rates: a systematic review." Bmj 338 (2009): a3162.

Rose, Arnold M. Theory and method in the social sciences. University of Minnesota Press, 1954.

Rumsey, S., D. P. Hurford, and A. K. Cole. "Influence of knowledge and religiousness on attitudes toward organ donation. " In Transplantation proceedings, vol. 35, no. 8, pp. 2845-2850. Elsevier, 2003.

Scanlon, Cole. Health Consequences of Legal Origin. Unpublished manuscript (2016), available at https://stanfordcomparativeadvantage.files.wordpress.com/2016/12/ scanlon-health-and-legal-origin.pdf [Accessed April 1, 2020].

Salim, Ali, Cherisse Berry, Eric J. Ley, Danielle Schulman, Chirag Desai, Sonia Navarro, and Darren Malinoski. "The impact of race on organ donation rates in Southern California." Journal of the American College of Surgeons, 211, no. 5 (2010): 596-600.

Shepherd, Lee, Ronan E. O'Carroll, and Eamonn Ferguson. "An international comparison of deceased and living organ donation/transplant rates in opt-in and opt-out systems: a panel study." BMC medicine 12, no. 1 (2014): 131. 
Shum, Eugene, and Arthur Chern. "Amendment of the human organ transplant act." Annals-Academy of Medicine Singapore 35, no. 6 (2006): 428.

Spamann, Holger. "Empirical Comparative Law". Annual Review of Law and Social Science, 11 (1) (2015): 131-153

Ugur, Zeynep Burcu. "Does presumed consent save lives? evidence from Europe." Health economics 24, no. 12 (2015): 1560-1572.

US Department of Health and Human Services, (2018), https://organdonor.gov/statistics-stories

US Department of State. Bureau of Democracy, Human Rights, and Labor: Australia 2016 international religious freedom report. Available at https://www.state.gov [Accessed May 9, 2018].

van Dalen, Hendrik P., and Kène Henkens. "Comparing the effects of defaults in organ donation systems." Social science $\&$ medicine 106 (2014): 137-142.

Wakefield, Claire E., Kaaren J. Watts, Judi Homewood, Bettina Meiser, and Laura A. Siminoff. "Attitudes toward organ donation and donor behavior: a review of the international literature." Progress in Transplantation 20, no. 4 (2010): 380-391.

Watson, C. J. E., and J. H. Dark. "Organ transplantation: historical perspective and current practice." In British journal of anaesthesia, 08, no. suppl_1 (2012): i29-i42.

Wong, L. P. "Factors limiting deceased organ donation: focus groups' perspective from culturally diverse community." In Transplantation proceedings, vol. 42, no. 5, pp. 1439-1444. Elsevier, 2010.

World Health Organization. "Study of Global Ageing and Adult Health." Available here: https://www. who.int/healthinfo/survey/SAGESurveyManualFinal.pdf (last accessed: April 1, 2020).

World Health Organization. "WHO Task Force on Donation and Transplantation of Human Organs and Tissues." Available here: https://www.who.int/transplantation/donation/ taskforce-transplantation/en/ (last accessed: April 1, 2020).

Zúñiga-Fajuri, Alejandra. "Increasing organ donation by presumed consent and allocation priority: Chile." Bulletin of the World Health Organization, 93 (2015): 199-202. 